\title{
Degrading Organic Micropollutants: The Next Challenge in the Evolution of Biological Wastewater Treatment Processes
}

\section{OPEN ACCESS}

Edited by:

Kostas A. Komnitsas,

Technical University of Crete, Greece

Reviewed by:

Dimitra Zaharaki,

Technical University of Crete, Greece

Georgios Bartzas,

National Technical University of

Athens, Greece

*Correspondence:

Naresh Singhal

n.singhal@auckland.ac.nz

Specialty section:

This article was submitted to

Wastewater Management,

a section of the journal

Frontiers in Environmental Science

Received: 06 April 2016 Accepted: 29 April 2016 Published: 18 May 2016

Citation:

Singhal N and Perez-Garcia O (2016)

Degrading Organic Micropollutants:

The Next Challenge in the Evolution of

Biological Wastewater Treatment

Processes. Front. Environ. Sci. 4:36.

doi: 10.3389/fenvs.2016.00036

\author{
Naresh Singhal * and Octavio Perez-Garcia \\ Department of Civil and Environmental Engineering, The University of Auckland, Auckland, New Zealand
}

Global water scarcity is driving the need for identifying new water source. Wastewater could be a potential water resource if appropriate treatment technologies could be developed. One of the barriers to obtaining high quality water from wastewater arises from the presence of organic micropollutants, which are biologically active at trace levels. Removal of these compounds from wastewater by current physico-chemical technologies is prohibitively expensive. While biological treatment processes are comparatively cheap, current systems are not capable of degrading the wide range of organic micropollutants present in wastewater. As current wastewater treatment processes were developed for treating conventional pollutants present at $\mathrm{mg} / \mathrm{L}$ levels, degrading the $\mathrm{ng} / \mathrm{L}$ levels of micropollutants will require a different approach to system design and operation. In this paper we discuss strategies that could be employed to develop biological wastewater treatment systems capable of degrading organic micropollutants.

Keywords: emerging contaminants, organic micropollutants, biocatalysis, metabolic diversity, biodegradation, oxidoreductases

\section{WASTEWATER, A WASTED RESOURCE}

The Oxford English Dictionary defines wastewater as superfluous water, or water that has served its purpose. This definition of wastewater is ingrained in our perception and attitude. Yet, this definition would appear to be outdated in light of the emerging view that wastewater represents an unutilized water resource and not a waste product to be discarded. Furthermore, promoting such use of wastewater is neither new nor radical. Virtually all urban societies already make use of water sources laden with wastewater, albeit in varying amounts. For example, consider the Mississippi, the longest river in North America, which serves as both a water source and wastewater receptor for the numerous towns and cities located along its path. As the river meanders downstream, water increasingly enriched by upstream discharges of wastewater serves as a source of potable water for downstream communities. Such observations support the view that wastewater is better defined as a potential water resource that is currently wasted. A third of the world's population lives in water-stressed countries and this proportion is expected to rise to two thirds by 2025 (Service, 2006). Finding alternate water sources is critical to the survival of these water stressed societies. Although wastewater has been overlooked as a potential water resource, it could become an option if appropriate treatment technologies can be developed. 
While biological treatment processes are significantly cheaper to build and operate, current designs are not capable of delivering high quality water suitable for a variety of purposes. Despite several advances since the inception of biological wastewater treatment processes, with an initial focus on removing organic carbon through to subsequent extension to include nitrogen and phosphorous removal, these systems continue to only be able to effectively degrade substances present at $\mathrm{mg} / \mathrm{L}$ concentrations.

Over the past decade the rapid increase in instrument sensitivity has led to wide detection of $\mathrm{ng} / \mathrm{L}$ levels of biologically active contaminants, referred to as emerging pollutants or organic micropollutants, in the environment. These contaminants include pharmaceuticals, personal care products, steroid hormones, industrial chemicals, and pesticides (Galloway et al., 2010; Oulton et al., 2010; Vandenberg et al., 2013; Richardson and Ternes, 2014; Petrie et al., 2015; Richardson and Kimura, 2016). Discharges from wastewater treatment plants are acknowledged as a major source of these contaminants in receiving environments (Spongberg and Witter, 2008; BarteltHunt et al., 2009; Loganathan et al., 2009). Various studies have highlighted the need to remove the $\mathrm{ng} / \mathrm{L}$ levels of these contaminants from the treated wastewater discharge due to their negative effect on human and animal health and ecotoxicology effects (Escher et al., 2011) - for example, a recent critical review concluded that doses of bisphenol A up to 4 orders of magnitude lower than the currently prescribed lowest observed adverse effect level of $50 \mathrm{mg} / \mathrm{kg} /$ day reliably produced effects in animals (Vandenberg et al., 2013) and another study reported changes in sex hormones associated with exposure to bisphenol A in men (Galloway et al., 2010). The cost of treating impacted environments can be large. London's drinking water is reported to be tainted with synthetic estrogens from excreted contraceptive pill residues in the Thames that have resulted from the water having gone through the equivalent of six people before reaching London. The cost of cleaning up Britain's contaminated waterways is estimated to exceed $£ 30$ bn (McKie, 2012). Development of appropriate technologies is needed to convert wastewater into a water resource, potentially even for meeting potable needs. This paper aims to stimulate a discussion on ways to enhance the performance of biological treatment systems to achieve this vision.

\section{CURRENT WASTEWATER TREATMENT APPROACHES}

The biological treatment approach, specifically the activated sludge process, is the most commonly used wastewater treatment technology. While it was originally designed to only remove organic carbon, it was subsequently extended to remove nitrogen and phosphorous. Transitioning between aerobic, anoxic, and anaerobic conditions is key to achieving biological nutrient removal. Doing so triggers the utilization of different electron acceptors and donors, therefore promoting the transformation of $\mathrm{C}, \mathrm{N}$, and $\mathrm{P}$ compounds. This strategy has continued to be exploited with the development of new system configurations, such as the Anammox (Lackner et al., 2014), SHARON (Hellinga et al., 1998; van Dongen et al., 2001), and Nareda (van der Roest et al., 2011) processes. Different redox environments influence organic micropollutant removal in different ways. Various studies have reported that organic micropollutant removal occurs to varying extent in biological treatment systems via a combination of biosorption and biodegradation. Maximum achievable removal for micropollutant such estrogens, nonylphenolics and metals was recorded at the highest sludge retention times (SRT) and hydraulic retention time (HRT) studied (Petrie et al., 2014). This micropollutant removal is related to the concomitant reduction in food: microorganism ratio. Nevertheless, studies have concluded that micropollutant degradation is insensitive to different SRTs (Falås et al., 2016). Other aspects influencing micropollutant removal in biological treatment processes are heterotrophic activity (Majewsky et al., 2010), pH (Gulde et al., 2014), and suspended/attached growth configuration (Falås et al., 2013). Although the heterogeneity of micropollutants in wastewaters makes removal difficult to predict since their chemistry is so diverse. For instance micropollutants can be broadly classified as easily, moderate and poorly degradable. The reality is that the biological processes are not designed to remove these pollutants, resulting in their incomplete removal and detection in final effluents and receiving surface waters (Joss et al., 2006; Racz and Goel, 2010). No specific strategies appear to have been successfully developed to enhance micropollutant removal by biological systems. Instead, organic micropollutant removal is typically achieved using physicochemical processes. These processes include adsorption in to organic matrices, passive effluent treatment in wetlands and aquifers, advanced oxidation processes (e.g., ozonation, UV treatment, photocatalysis, and Fenton oxidation), membrane filtration (nanofiltration and reverse osmosis membranes), and membrane biological reactor (Bolong et al., 2009; Rossner et al., 2009; Oulton et al., 2010; Luo et al., 2014). The shortcomings of these treatment systems are high investment and maintenance costs, generation of toxic residuals, and complex treatment procedures (Grassi et al., 2012). Operational difficulties of these physicochemical processes also need to be considered. For instance, wetlands and aquifers require large surface areas and large HRTs, which significantly complicates its implementation in urban areas. Similarly, advanced oxidation processes require chemicals not easily available (e.g., $\mathrm{O}_{3}, \mathrm{~F}_{2}^{+}$, $\mathrm{H}_{2} \mathrm{O}_{2}$ ) and the non-selective nature of these reactions can result in formation of daughter products that are more toxic than the parent micropollutant (Rosal et al., 2009). Other concerns may also need consideration: energy and chemical inputs of ozonation processes are substantial (Cañizares et al., 2009); the Fenton process requires rigorous $\mathrm{pH}$ control (Chong et al., 2012); specially configured reactors are needed to maximize light exposure by UV and photocatalysis based water treatment, or water turbidity could significantly influence treatment efficiency (Chong et al., 2012); and membrane filtration and membrane biological reactors treatments routinely suffer from membrane fouling and biofilm formation (Guo et al., 2012). 


\section{ENHANCING BIOLOGICAL WASTEWATER TREATMENT}

\section{Exploiting Microbial Diversity}

Complex microbial consortia composed by bacteria-bacteria, bacteria-archea and bacteria-fungi can be developed to enhance biological degradation of micropollutants. Oxidase enzymes have great potential as biocatalysts for micropollutant and organic waste breakdown. Two of such class of enzymes are the oxygenase Cytochromes P450 (CYPs or Cyt P450), a highly efficient group of monooxygenases responsible for the destruction of drugs and toxins in organisms, and the laccases (EC 1.10.3.2), a class of copper-containing oxidase enzymes used by microorganisms to break down lignin) (Riva, 2006; Kumar, 2010). Both enzymes have been shown to efficiently degrade a vast array of organic micropollutants in pure enzyme assays (Harms et al., 2011; Lah et al., 2011). Despite the demonstrated effectiveness of these enzymes, their use in wastewater treatment is just starting to be investigated and has not been implemented in pilot or full scale (Lah et al., 2011). Current biological systems are reliant on using prokaryotic bacteria, which can rapidly oxidize organic carbon but generally do not express Cyt P450. Additionally, no applications of bacterial laccases have yet been realized due to their limited characterization (WerckReichhart and Feyereisen, 2000). In comparison, many fungi produce Cyt P450 (Lah et al., 2008; Kelly and Kelly, 2013) and only fungal laccases are used currently in biotechnological applications (Sharma et al., 2007; Harms et al., 2011). A system integrating suspended phase bacteria with activated fungi to transform conventional and emerging categories of pollutants can potentially take advantage of both organisms. Fungi can be activated by inducing the production of high levels of oxidase enzymes and at the same time stimulating enzyme activity (e.g., by providing $\mathrm{H}_{2} \mathrm{O}_{2}$ as cofactor for bacterial Cyt P450). By controlling the carbon source and electron acceptor regimens, it is possible to induct biocatalyst expression and activation (Price et al., 2013; Chubukov et al., 2014). As wholecell catalyzed reactions are reportedly 10- to 100 -fold slower than reactions catalyzed by free enzymes (Sotirova et al., 2008), cell membranes can be permeabilized to enhance extracellular laccase secretion and promote cellular influx of pollutants to membrane bound Cyt P450. In addition, gel encapsulated of fungi or bacterial cells can be implemented for improved performance. Alternatively, iterating between different redox conditions can promote the growth of different microbial populations to improve micropollutant biodegradation (Falås et al., 2016).

\section{Exploiting Metabolic Diversity}

New bioprocesses to treat wastewater can be developed by exploiting the diverse metabolic capabilities of microbes. Traditionally, only metabolic capabilities in relation to aerobic heterotrophy, aerobic nitrification and anoxic denitrification, and phosphate accumulation have been used in biological wastewater treatment systems. Exploiting alternative metabolic capabilities such as heterotrophic sulfate-reduction (Zhang and Wang, 2014), autotrophic sulfur-oxidizing denitrification (Hao et al., 2014; Pokorna and Zabranska, 2015), anaerobic methaneoxidation denitrification (Raghoebarsing et al., 2006), partial nitrite reduction to nitrous oxide for energy generation (Scherson et al., 2013) and electron shuttle redox biotransformation (Van der Zee and Cervantes, 2009) could improve micropollutant removal from wastewaters. These metabolic capabilities can also be exploited to remove inorganic micropollutants (e.g., heavy metals and radioactive elements) in which redox transformations can alter the solubility and precipitate the contaminants (Groudev et al., 1999; Gadd, 2010).

\section{Exploiting Biocatalyst Diversity}

Many enzymes are "promiscuous" biocatalysts capable of transforming a variety of substrates that share structural similarity with their primary substrate. These promiscuous or generalized enzymes: (i) are frequently not essential, (ii) maintain low metabolic fluxes, and (iii) require less regulation of enzyme activity to control metabolic flux in dynamic environments than do specialized enzymes (Nam et al., 2012). This non-specificity makes them promising biocatalysts for organic micropollutant degradation. Bacteria are constantly developing new catabolic pathways in order to either access sources of carbon, energy and nutrients or simply to detoxify new compounds. However, unraveling these degradation processes in nature is made difficult by the large number of chemicals, their occurrence at mostly low concentrations, and the number of unknown chemicals resulting from bacterial transformation and biodegradation. Genomics has revealed that many microorganisms have far greater potential to produce specialized enzymes and metabolites than was thought from classic bioactivity screens; however, realizing their degradation potential has been hampered by the fact that many specialized metabolite biosynthetic gene clusters are not expressed in laboratory cultures (Keller et al., 2005; Miller et al., 2010; Mora-Pale et al., 2014; Rutledge and Challis, 2015). Theoretically bacteria can utilize the full space of catabolic biochemical reaction types and initiate several pathways to degrade micropollutants (Kolvenbach et al., 2014). For example, multiple biodegradation mechanisms have been discovered for bisphenol A (BPA), an industrial chemical found in a variety of plastics and epoxies and a putative endocrine disrupting compound. Similarly, enzymatic biodegradation pathways may be discoverable for other compounds using biocatalyst and daughter products screening techniques such as metagenomics (Fernández-Arrojo et al., 2010), metaproteomics, and metabolomics (Villas-Bôas and Bruheim, 2007; Helbling et al., 2010, 2012).

\section{IMPLEMENTATION}

Current designs focus on removing conventional pollutants (organic and inorganic substances present) that are present at much larger concentrations than micropollutants to be metabolized as a source of carbon and energy. The low concentrations of organic micropollutants suggests that these substances are more likely to be cometabolized. Hence, system design will need to focus on ways of stimulating the production of enzymes that could degrade the micropollutants. 
Current wastewater treatment system designs contain the basic ingredients required to formulate new processes for efficiently degrading micropollutants using the strategies discussed in the sections above. Biological treatment systems contain a wide variety of active microorganisms, and employ different redox environments are used to stimulate a wider range of chemical transformations. Rapid degradation of micropollutants could be achieved by stimulating the production of enzymes (e.g., oxidoreductases and laccases) by using hard-to-degrade substrates or by employing other environmental stresses. Liquids from anaerobic digestate could serve as carbon source that promotes such activity. The performance of such systems could be further enhanced by employing operational strategies that avert a lowering of enzyme production resulting from adaptation of microbial consortium to the imposed stress. Two plant configurations could potentially be developed using these approaches: (i) main stream micropollutant removal (i.e., modification of existing bioprocesses) or (ii) add-on reactors for micropollutant removal (i.e., dedicated tanks to remove micropollutants in the effluent of treatment plant).

\section{REFERENCES}

Bartelt-Hunt, S. L., Snow, D. D., Damon, T., Shockley, J., and Hoagland, K. (2009). The occurrence of illicit and therapeutic pharmaceuticals in wastewater effluent and surface waters in Nebraska. Environ. Pollut. 157, 786-791. doi: 10.1016/j.envpol.2008.11.025

Bolong, N., Ismail, A. F., Salim, M. R., and Matsuura, T. (2009). A review of the effects of emerging contaminants in wastewater and options for their removal. Desalination 239, 229-246. doi: 10.1016/j.desal.2008.03.020

Cañizares, P., Paz, R., Sáez, C., and Rodrigo, M. A. (2009). Costs of the electrochemical oxidation of wastewaters: a comparison with ozonation and Fenton oxidation processes. J. Environ. Manag. 90, 410-420. doi: 10.1016/j.jenvman.2007.10.010

Chong, M. N., Sharma, A. K., Burn, S., and Saint, C. P. (2012). Feasibility study on the application of advanced oxidation technologies for decentralised wastewater treatment. J. Cleaner Prod. 35, 230-238. doi: 10.1016/j.jclepro.2012.06.003

Chubukov, V., Gerosa, L., Kochanowski, K., and Sauer, U. (2014). Coordination of microbial metabolism. Nat. Rev. Microbiol. 12, 327-340. doi: $10.1038 /$ nrmicro3238

Escher, B. I., Baumgartner, R., Koller, M., Treyer, K., Lienert, J., and McArdell, C. S. (2011). Environmental toxicology and risk assessment of pharmaceuticals from hospital wastewater. Water Res. 45, 75-92. doi: 10.1016/j.watres.2010.08.019

Falås, P., Longrée, P., la Cour Jansen, J., Siegrist, H., Hollender, J., and Joss, A. (2013). Micropollutant removal by attached and suspended growth in a hybrid biofilm-activated sludge process. Water Res. 47, 4498-4506. doi: 10.1016/j.watres.2013.05.010

Falås, P., Wick, A., Castronovo, S., Habermacher, J., Ternes, T. A., and Joss, A. (2016). Tracing the limits of organic micropollutant removal in biological wastewater treatment. Water Res. 95, 240-249. doi: 10.1016/j.watres.2016.03.009

Fernández-Arrojo, L., Guazzaroni, M. E., López-Cortés, N., Beloqui, A., and Ferrer, M. (2010). Metagenomic era for biocatalyst identification. Curr. Opin. Biotechnol. 21, 725-733. doi: 10.1016/j.copbio.2010.09.006

Gadd, G. M. (2010). Metals, minerals and microbes: Geomicrobiology and bioremediation. Microbiology 156, 609-643. doi: 10.1099/mic.0.037143-0

Galloway, T., Cipelli, R., Guralnick, J., Ferrucci, L., Bandinelli, S., Corsi, A. M., et al. (2010). Daily bisphenol a excretion and associations with sex hormone

\section{CONCLUSIONS}

Numerous organic micropollutants are present in wastewater. To convert wastewater into high quality water will require their removal. Current wastewater treatment systems are not designed to degrade organic micropollutants. Physicochemical treatment systems are effective but expensive while biological approaches cheap but ineffective and inconsistent. The next stage in the evolution of biological wastewater treatment processes could be based on discovering and employing novel metabolic traits of unconventional microbes (e.g., sulfur or iron oxidizing bacteria), or inducing the synthesis of enzymes capable of degrading micropollutants. Implementation of these new bioprocesses will involve the use of different waste streams used as substrate and new process operation strategies such as dynamic substrates control.

\section{AUTHOR CONTRIBUTIONS}

NS developed the overall concept. NS and OP equally contributed to the writing of the article. concentrations: results from the inchianti adult population study. Environ. Health Perspect. 118, 1603-1608. doi: 10.1289/ehp.1002367

Grassi, M., Belgiorno, V., and Lofrano, G. (2012)."Removal of emerging contaminants from water and wastewater by adsorption process," in Emerging Compounds Removal from Wastewater, ed G. Lofrano (New York, NY: Springer), p15-p37.

Groudev, S. N., Bratcova, S. G., and Komnitsas, K. (1999). Treatment of waters polluted with radioactive elements and heavy metals by means of a laboratory passive system. Minerals Eng. 12, 261-270. doi: 10.1016/S0892-6875(99) 00004-7

Gulde, R., Helbling, D. E., Scheidegger, A., and Fenner, K. (2014). pHdependent biotransformation of ionizable organic micropollutants in activated sludge. Environ. Sci. Technol. 48, 13760-13768. doi: 10.1021/es50 37139

Guo, W., Ngo, H.-H., and Li, J. (2012). A mini-review on membrane fouling. Bioresour. Technol. 122, 27-34. doi: 10.1016/j.biortech.2012.04.089

Hao, T.-W., Xiang, P., Mackey, H. R., Chi, K., Lu, H., Chui, H., et al. (2014). A review of biological sulfate conversions in wastewater treatment. Water Res. 65, 1-21. doi: 10.1016/j.watres.2014.06.043

Harms, H., Schlosser, D., and Wick, L. Y. (2011). Untapped potential: exploiting fungi in bioremediation of hazardous chemicals. Nat. Rev. Microbiol. 9, 177-192. doi: 10.1038/nrmicro2519

Helbling, D. E., Hollender, J., Kohler, H.-E., Singer, H., and Fenner, K. (2010). High-throughput identification of microbial transformation products of organic micropollutants. Environ. Sci. Technol. 44, 6621-6627. doi: $10.1021 / \mathrm{es} 100970 \mathrm{~m}$

Helbling, D. E., Johnson, D. R., Honti, M., and Fenner, K. (2012). Micropollutant biotransformation kinetics associate with WWTP process parameters and microbial community characteristics. Environ. Sci. Technol. 46, 10579-10588. doi: 10.1021/es3019012

Hellinga, C., Schellen, A. A. J. C., Mulder, J. W., van Loosdrecht, M. C. M., and Heijnen, J. J. (1998). The sharon process: an innovative method for nitrogen removal from ammonium-rich waste water. Water Sci. Technol. 37, 135-142. doi: 10.1016/S0273-1223(98)00281-9

Joss, A., Zabczynski, S., Göbel, A., Hoffmann, B., Löffler, D., McArdell, C. S., et al. (2006). Biological degradation of pharmaceuticals in municipal wastewater treatment: proposing a classification scheme. Water Res. 40, 1686-1696. doi: 10.1016/j.watres.2006.02.014 
Keller, N. P., Turner, G., and Bennett, J. W. (2005). Fungal secondary metabolism - From biochemistry to genomics. Nat. Rev. Microbiol. 3, 937-947. doi: $10.1038 /$ nrmicro1286

Kelly, S. L., and Kelly, D. E. (2013). Microbial cytochromes P450: biodiversity and biotechnology. Where do cytochromes P450 come from, what do they do and what can they do for us? Philos. Trans. R. Soc. B 368, 20120476. doi: $10.1098 /$ rstb.2012.0476

Kolvenbach, B. A., Helbling, D. E., Kohler, H.-P. E., and Corvini, P. F.-X. (2014). Emerging chemicals and the evolution of biodegradation capacities and pathways in bacteria. Curr.Opin. Biotechnol. 27, 8-14. doi: 10.1016/j.copbio.2013.08.017

Kumar, S. (2010). Engineering cytochrome P450 biocatalysts for biotechnology, medicine and bioremediation. Expert Opin. Drug Metab. Toxicol. 6, 115-131. doi: $10.1517 / 17425250903431040$

Lackner, S., Gilbert, E. M., Vlaeminck, S. E., Joss, A., Horn, H., and van Loosdrecht, M. C. M. (2014). Full-scale partial nitritation/anammox experiences - an application survey. Water Res. 55, 292-303. doi: 10.1016/j.watres.2014.02.032

Lah, L., Kraševec, N., Trontelj, P., and Komel, R. (2008). High diversity and complex evolution of fungal cytochrome P450 reductase: cytochrome P450 systems. Fungal Genet. Biol. 45, 446-458. doi: 10.1016/j.fgb.2007.10.004

Lah, L., Podobnik, B., Novak, M., Korošec, B., Berne, S., Vogelsang, M., et al. (2011). The versatility of the fungal cytochrome P450 monooxygenase system is instrumental in xenobiotic detoxification. Mol. Microbiol. 81, 1374-1389. doi: 10.1111/j.1365-2958.2011.07772.x

Loganathan, B., Phillips, M., Mowery, H., and Jones-Lepp, T. L. (2009). Contamination profiles and mass loadings of macrolide antibiotics and illicit drugs from a small urban wastewater treatment plant. Chemosphere 75, 70-77. doi: 10.1016/j.chemosphere.2008.11.047

Luo, Y., Guo, W., Ngo, H. H., Nghiem, L. D., Hai, F. I., Zhang, J., et al. (2014). A review on the occurrence of micropollutants in the aquatic environment and their fate and removal during wastewater treatment. Sci. Total Environ. 473-474, 619-641. doi: 10.1016/j.scitotenv.2013.12.065

Majewsky, M., Gallé, T., Zwank, L., and Fischer, K. (2010). Influence of microbial activity on polar xenobiotic degradation in activated sludge systems. Water Sci. Technol. 62, 701-707. doi: 10.2166/wst.2010.925

McKie, R. (2012). Drug and water firms attack EU plan to reduce ethinylestradiol pollution. BMJ 344:4029. doi: 10.1136/bmj.e4029

Miller, L. D., Mosher, J. J., Venkateswaran, A., Yang, Z. K., Palumbo, A. V., Phelps, T. J., et al. (2010). Establishment and metabolic analysis of a model microbial community for understanding trophic and electron accepting interactions of subsurface anaerobic environments. BMC Microbiol. 10:149. doi: 10.1186/14712180-10-149

Mora-Pale, M., Sanchez-Rodriguez, S. P., Linhardt, R. J., Dordick, J. S., and Koffas, M. A. G. (2014). Biochemical strategies for enhancing the in vivo production of natural products with pharmaceutical potential. Curr. Opin. Biotechnol. 25, 86-94. doi: 10.1016/j.copbio.2013.09.009

Nam, H., Lewis, N. E., Lerman, J. A., Lee, D., Chang, R. L., Kim, D., et al. (2012). Network context and selection in the evolution to enzyme specificity. Science 337, 1101-1104. doi: 10.1126/science.1216861

Oulton, R. L., Kohn, T., and Cwiertny, D. M. (2010). Pharmaceuticals and personal care products in effluent matrices: a survey of transformation and removal during wastewater treatment and implications for wastewater management. J. Environ. Monit. 12, 1956-1978. doi: 10.1039/c0em00068j

Petrie, B., Barden, R., and Kasprzyk-Hordern, B. (2015). A review on emerging contaminants in wastewaters and the environment: current knowledge, understudied areas and recommendations for future monitoring. Water Res. 72, 3-27. doi: 10.1016/j.watres.2014.08.053

Petrie, B., McAdam, E. J., and Lester, J. N., Cartmell, E. (2014). Assessing potential modifications to the activated sludge process to improve simultaneous removal of a diverse range of micropollutants. Water Res. 62, 180-192. doi: 10.1016/j.watres.2014.05.036

Pokorna, D., and Zabranska, J. (2015). Sulfur-oxidizing bacteria in environmental technology. Biotechnol. Adv. 33, 1246-1259. doi: 10.1016/j.biotechadv.2015.02.007

Price, M. N., Deutschbauer, A. M., Skerker, J. M., Wetmore, K. M., Ruths, T., Mar, J. S., et al. (2013). Indirect and suboptimal control of gene expression is widespread in bacteria. Mol. Sys. Biol. 9, 660. doi: 10.1038/msb.2013.16

Racz, L., and Goel, R. (2010). Fate and removal of estrogens in municipal wastewater. J. Environ. Monit. 12, 58-70. doi: 10.1039/B917298]
Raghoebarsing, A. A., Pol, A., van de Pas-Schoonen, K. T., Smolders, A. J. P., Ettwig, K. F., Rijpstra, W. I. C., et al. (2006). A microbial consortium couples anaerobic methane oxidation to denitrification. Nature 440, 918-921. doi: 10.1038/nature04617

Richardson, S. D., and Kimura, S. Y. (2016). Water analysis: emerging contaminants and current issues. Anal. Chem. 88, 546-582. doi: 10.1021/acs.analchem.5b04493

Richardson, S. D., and Ternes, T. A. (2014). Water analysis: emerging contaminants and current issues. Anal. Chem. 86, 2813-2848. doi: $10.1021 /$ ac500508t

Riva, S. (2006). Laccases: blue enzymes for green chemistry. Trends Biotechnol. 24, 219-226. doi: 10.1016/j.tibtech.2006.03.006

Rosal, R., Gonzalo, M. S., Boltes, K., Letón, P., Vaquero, J. J., and García-Calvo, E. (2009). Identification of intermediates and assessment of ecotoxicity in the oxidation products generated during the ozonation of clofibric acid. J. Hazard. Mat. 172, 1061-1068. doi: 10.1016/j.jhazmat.2009.07.110

Rossner, A., Snyder, S. A., and Knappe, D. R. U. (2009). Removal of emerging contaminants of concern by alternative adsorbents. Water Res. 43, 3787-3796. doi: 10.1016/j.watres.2009.06.009

Rutledge, P. J., and Challis, G. L. (2015). Discovery of microbial natural products by activation of silent biosynthetic gene clusters. Nat. Rev. Microbiol. 13, 509-523. doi: 10.1038/nrmicro3496

Scherson, Y. D., Wells, G. F., Woo, S.-G., Lee, J., Park, J., Cantwell, B. J., et al. (2013). Nitrogen removal with energy recovery through $\mathrm{N}_{2} \mathrm{O}$ decomposition. Energy Environ. Sci. 6, 241-248. doi: 10.1039/C2EE22487A

Service, R. F. (2006). Desalination freshens up. Science 313, 1088-1090. doi: 10.1126/science.313.5790.1088

Sharma, P., Goel, R., and Capalash, N. (2007). Bacterial laccases. World J. Microbiol. Biotechnol. 23, 823-832. doi: 10.1007/s11274-006-9305-3

Sotirova, A. V., Spasova, D. I., Galabova, D. N., Karpenko, E., and Shulga, A. (2008). Rhamnolipid-biosurfactant permeabilizing effects on gram-positive and gramnegative bacterial strains. Curr. Microbiol. 56, 639-644. doi: 10.1007/s00284008-9139-3

Spongberg, A. L., and Witter, J. D. (2008). Pharmaceutical compounds in the wastewater process stream in Northwest Ohio. Sci. Total Environ. 397, 148-157. doi: 10.1016/j.scitotenv.2008.02.042

Vandenberg, L. N., Ehrlich, S., Belcher, S. M., Ben-Jonathan, N., Dolinoy, D. C., Hugo, E. R., et al. (2013). Low dose effects of bisphenol A: an integrated review of in vitro, laboratory animal, and epidemiology studies. Endocr. Disrupt. 1, 25078. doi: 10.4161/endo. 26490

van der Roest, H. F., de Bruin, L. M. M., Gademan, G., and Coelho, F. (2011). Towards sustainable waste water treatment with Dutch Nereda ${ }^{\circledR}$ technology. Water Pract. Technol. 6, 1-2. doi: 10.2166/wpt.2011.059

Van der Zee, F. P., and Cervantes, F. J. (2009). Impact and application of electron shuttles on the redox (bio)transformation of contaminants: a review. Biotechnol. Adv. 27, 256-277. doi: 10.1016/j.biotechadv.2009. 01.004

van Dongen, U., Jetten, M. S., and van Loosdrecht, M. C. (2001). The SHARONAnammox process for treatment of ammonium rich wastewater. Water Sci. Technol. 44, 153-160.

Villas-Bôas, S. G., and Bruheim, P. (2007). The potential of metabolomics tools in bioremediation studies. OMICS A J. Integr. Biol. 11, 305-313. doi: 10.1089/omi.2007.0005

Werck-Reichhart, D., and Feyereisen, R. (2000). Cytochromes P450: a success story. Genome Biol. 1:reviews3003. doi: 10.1186/gb-2000-1-6-reviews3003

Zhang, M., and Wang, H. (2014). Organic wastes as carbon sources to promote sulfate reducing bacterial activity for biological remediation of acid mine drainage. Minerals Eng. 69, 81-90. doi: 10.1016/j.mineng.2014.07.010

Conflict of Interest Statement: The authors declare that the research was conducted in the absence of any commercial or financial relationships that could be construed as a potential conflict of interest.

Copyright (c) 2016 Singhal and Perez-Garcia. This is an open-access article distributed under the terms of the Creative Commons Attribution License (CC BY). The use, distribution or reproduction in other forums is permitted, provided the original author(s) or licensor are credited and that the original publication in this journal is cited, in accordance with accepted academic practice. No use, distribution or reproduction is permitted which does not comply with these terms. 